\title{
DOI 10.31392/NPU-nc.series15.2021.5(135).02
}

\author{
Martynov Yu. \\ senior lecturer at the Department of Physical Education \\ Koryukaev $M$. \\ senior lecturer at the Department of Physical Education \\ Sobolenko A., \\ senior lecturer at the Department of Physical Education \\ National Technical University of Ukraine \\ "Kyiv Polytechnic Institute named after Igor Sikorsky"
}

\section{ADVANCING PHYSICAL TRAINING OF STUDENTS FOR ATHLETICISM}

The article reveals the peculiarities of the use of athletics to improve the physical fitness of students of higher education institutions. The influence of physical education on motivation for athletics is also revealed.

It is established that the use of means and methods of athletics in physical education classes in higher education institutions leads to a significant increase in the level of physical fitness.

It was found that one of the factors influencing the growth of student morbidity and low level of their physical development is the lack of physical activity. The combination of these factors determines the level of physical fitness and efficiency, which, in turn, are important indicators of professional training of students.

However, the use of other methods of strength development, the method of unsatisfactory efforts with a normalized number of repetitions, the method of unsatisfactory efforts with the maximum number of repetitions, the method of dynamic efforts, the shock method, the method of static efforts, the static-dynamic method, the method of circular training, the game method has a beneficial effect on the development of all physical qualities.

The decrease in the indicators of general physical fitness is facilitated by the fact that during the holidays, students practically do not go in for sports on their own. As the analysis of the survey has shown, only students of higher educational institutions are independently engaged in physical culture.

Key words: athletics, students, physical education, physical activity, physical fitness.

Мартинов Ю. О., Корюкаєв М. М., Соболенко А. І. Підвищення рівня фізичної підготовленості студентів засобами атлетизму. В статті розкрито особливості використання засобів атлетизму для підвищення фрізичної підготовленості студентів закладів вищої освіти. Також розкрито вплив фрізичного виховання на мотивацію до занять 3 атлетизму.

Встановлено, що використання засобів і методів атлетизму на навчальних заняттях з фізичного виховання в закладах вищої освіти призводить до достовірного підвищення рівня фрізичної підготовленості.

Виявлено, що одним із фракторів впливу на зростання захворюваності студентів і низький рівень їх фрізичного розвитку є дефіцит рухової активності. Сукупність зазначених чинників обумовлює рівень фрізичної підготовленості $i$ працездатності, які, в свою чергу, є важливими показниками професійної підготовки студентів.

Ключові слова: атлетизм, студенти, фізичне виховання, рухова активність, ффізична підготовленість.

Formulation of the problem. The relevance of the topic is due to the lack of research on issues covering the use of means and methods of athleticism to improve the physical fitness of university students in the framework of academic studies for a long time, as well as the lack of necessary developments in this area and the lack of constant monitoring of health, physical fitness using the means of general physical training and athleticism among students of higher educational institutions. The lack of free time due to the high academic load at the university increases the relevance of physical culture classes, which are one of the few available means of increasing the physical activity of students. The value of physical culture lessons increases due to the impossibility of visiting the main part of student youth in many sports sections because of their activities on a self-sustaining basis.

Classes in athleticism without observing the basic rules of the technique of motor actions, uncontrolled fulfillment of exercises not only does not help, but can also turn out to be dangerous for the health of students. In addition, the importance of this issue is due to the growing interest of young people in this type of physical activity, the preservation of a stable positive motivation of those involved, as well as the development and popularization of strength sports.

Physical culture is an organic part of universal culture, its special independent area aimed at the recovery of man and the development of his physical abilities. In higher education, it acts as a necessary part of the student's lifestyle, as it is a means of meeting vital needs in physical activity. In addition, physical culture promotes the development of a harmonious personality, physical improvement and reflects a certain degree of physical development of the student, his motor skills and allows him to most fully realize their creative potential.

The result of activity in physical culture is physical fitness and the degree of perfection of motor skills, high level of development of vital forces, sports achievements, moral, aesthetic, intellectual development. Physical culture most fully carries out the educational and developing functions in purposeful pedagogical process of physical education.

Physical education - a pedagogical process aimed at morphological and functional improvement of the human body, the formation and improvement of its basic vital motor skills, abilities and related knowledge.

Physical education of students, first, should provide a high degree of development of motor skills, acquisition of knowledge, skills and abilities necessary for successful professional activity in order to increase educational activity, maintain and promote 
health. Second, involve students in regular exercise. Third, to promote the development of social activity, to influence the formation of the spiritual world, moral and aesthetic development of the student's personality.

Analysis of literary sources. The analysis of literary sources testifies to the deterioration of health, an increase in morbidity, various deviations in the state of health of modern youth. Along with the increase in morbidity among students, there is a deterioration in physical health indicators, their inconsistency with generally accepted norms. Among the factors influencing the growth of students' morbidity and the low level of their physical development, the deficit of physical activity should be noted. The combination of these factors determines the level of physical fitness and working capacity, which, in turn, are important indicators of students' professional training.

The analysis of physical culture training lessons on the specialization "Athleticism" for four years has been carried out. During the entire training period, the following indicators were used: the use of maximum load with the use of powerlifting exercises in young men, the use of the most common methods aimed at educating various types of strength abilities, the use of various modes of muscle activity, the number of exercises and their sequence, the use of exercises.

Presentation of the main research material. One of the factors in the popularity of athletic gymnastics is the ability to accurately dose the load and size

encumbrances, which makes it widely available for people of all ages, genders, health conditions. Athletics, as a direction of strength training, is currently especially popular in the environment student youth. The number of those involved in various types of athletics is growing, the number of studies is increasing scientific and methodological literature.

The technique of using strength exercises from the arsenal of athletic gymnastics is revealed for professional and applied training of female students. It would be expedient to hold annual competitions in higher education institutions among girls in powerlifting, who are very popular. There is an increase in interest in acquiring special theoretical knowledge on strength training. The result of these classes is expressed in the fact that those students who are regularly engaged in strength exercises, successfully make such standards as: lifting the torso, lying on

back; lifting the torso from a supine position and squats [6].

The most effective effect on improving the physical fitness of "circular training", which includes performing athletic exercises of different orientation (isotonic and isokinetic) - performing exercises on simulators.

Theoretical analysis and generalization of literary sources, the results of their own pedagogical experience confirm the fact that the most acute problem facing higher education is a serious deterioration in health student youth. In the system of life values, students' health is low. In a study of interest in physical education classes, it was found use. Athletic exercises have a positive effect on improving motivation.

It is known that rational motor activity is a powerful factor that increases the adaptive capacity of the organism, expands the functional reserves of student youth. A number of authors agree that the modern system of the physical education of students, for all its diversity, currently has not been able to involve in regular physical education exercises the bulk of student youth [3].

An important component of athletics classes is the implementation of an individual approach that involves methodical development of three main structures in the system control unit, namely: substantiation of the quantitatively expressed level preparedness that students must have; obtaining a quantitative assessment of the level of preparedness at the beginning and on the course of the pedagogical process; the presence of corrective effects on the level of preparedness of the object (subject) of teaching process [2].

Great potential in increasing motor activity and in the formation of motivation to systematic physical education classes are the introduction of athletics as one of the modern means of physical education.

The most acute problem facing higher education today is a serious deterioration in the health of student youth. This is especially true for freshmen due to their lack of experience in adapting to the new socio-economic and psychological-pedagogical status of the student. It is alarming that the majority of students are not able to give an objective assessment of their health. Health is far from the leading place in the youth value system. The existing system of physical education in higher educational institutions does not solve its main and important task - maintaining the state of health and physical fitness of students at the modern level. It does not take into account the interests and needs of students, does not contribute to sustainable motivation for motor activity, the formation of physical culture of the student's personality.

Analysis and generalization of literary sources, practical experience of higher education, reflecting the state of the problem, brought out the following. The main problem faced by teachers of physical education in a higher educational institution is the contradiction between the need for a healthy lifestyle by students, strengthening and developing their health and the lack of real steps on their part in this direction. The most typical problems are a high level of sickness among students, a low level of physical fitness, insufficient provision from the department of students' needs in various forms of physical culture.

An important factor is the introduction of independent and additional physical exercises into everyday life. Since two-time classes per week, as well as long breaks associated with examination sessions and vacations do not provide a positive effect from physical activity.

A variety of new means and forms of physical activity is manifested in physical recreation, which is reflected in the works.

A number of studies are devoted to various issues of classes with burdens my student youth. However, the goal of these studies was mainly the sports aspects of athletic gymnastics to develop strength and body proportions in accordance with bodybuilding standards or body type. The developed methods did not take into account the specifics of higher education. A new direction of training with weights is their recreational orientation, ensuring well-being and health.

Therefore, the main directions of forming a healthy lifestyle of students by means of athletics. Formation and improvement of the system of knowledge about human health and the factors influencing the formation and health support.

Increasing the system of motivation of students to use physical exercises in everyday life. Formation and improvement of the system of skills and abilities to lead a healthy lifestyle. Development of new tools and forms of motor activity [3]. 
Based on the work done, we recommend using in the educational process of university students the curriculum developed by us for the specialization "Athleticism", with an emphasis on the development of strength abilities.

Based on the obtained experimental data, assigned to physical culture training sessions, was assigned to strength exercises, while the positive effect of educational and training sessions increased. These include bodybuilding, powerlifting and weightlifting exercises (for boys) and fitness, calanetics, bodybuilding, and aerobic exercises (for girls).

Physical education classes on the specialization "Athleticism" allow you to achieve the proper level of physical fitness, provided that it is carried out at least twice a week. They form a motivational-value attitude to physical culture, an attitude towards self-education, the need for regular exercise and sports. They help to master a system of practical skills and abilities that ensure the preservation and strengthening of their own health, mental well-being, the development and improvement of psychophysical abilities, qualities, personality traits, self-determination in physical culture (choice of specialization).

We recommend physical culture classes, in particular athleticism, which provide general physical fitness, gaining experience in the creative use of physical culture and sports activities to achieve life goals. They identify promising athletes, develop an interest in training, thereby giving students the opportunity to show their abilities in competitions in strength sports.

In the course of the experimental work, we developed a table for assessing the level of strength readiness (for beginners) for students of the university's young men on the specialization "Athleticism". We recommend using the table of strength readiness of young men of different weight categories as evaluation criteria, which determines the level of strength readiness depending on the course of study at the initial stage of training.

In order to increase the level of strength readiness among young men in powerlifting exercises, based on the linear correlation method, we recommend using power triathlon exercises for the greatest effect. The rest (special-auxiliary, developmental, leading) exercises can also be used in physical culture classes at a university to increase the level of strength readiness of students, but this effect from the load will be much less than when using powerlifting exercises directly.

Conclusion. Analyzing publications on athletics, we can conclude that the works are worn diverse nature. Examples of the positive effect of strength training on the body of young people are given. Revealed methods of training with weights and a combination of strength exercises with cyclic locomotion. Topical issues are revealed nutrition in bodybuilding. There are no data on weightlifting and powerlifting in the analyzed works. If tournaments with weightlifting. Which in the past were very popular in higher education institutions, have now lost their status, then. Athletics is one of the most popular types of strength training among student youth. These data indicate the relevance further study of the impact of classes on the health and physical qualities of student youth, the development of effective means, methods and forms of sports and health work, using means of athletics.

\section{Literature}

1. Hayduk I. (2012) Atletychna himnastyka v systemi fizychnoho vykhovannya ditey starshoho shkil'noho viku. Moloda sportyvna nauka Ukrayiny. - L'viv : LDUFK. - Vyp. 10. - T. 1. - S. 141-144.

2. Gakh R. (2013) Athletic gymnastics in the system of physical education of students-economists of another rock of the world // Physical fitness, sports and culture of health in a modern suspension: zb. sciences. pr. - No1 (21). p. 153-156.

3. Kanishevs'kyy S. M. (2008) Umovy, stan i perspektyvy rozvytku fizychnoho vykhovannya u vuzakh Ukrayiny // Teoriya i praktyka fizychnoho

vykhovannya. - № 1. - S. 139-145.

4. Krutsevych T. Yu. (2008) Spryamovanist' tsinnostey indyvidual'noyi fizychnoyi kul'tury studentiv riznykh viddilen' vuzu // Sportyvnyy visnyk Prydniprov"ya. - № 3-4. - S. 103-107.

5. Lynets' M. (1997) Osnovy metodyky rozvytku rukhovykh yakostey : navch. posib. dlya fizkul'turnykh vuziv / M. Lynets'. L'viv : Shtabor. $-204 \mathrm{~s}$.

6. Lavrenyuk V. S. (2011) Udoskonalen-nya power health of students in the initial process of physical education /I Pedagogy, psycho-logic and medical-biological problems of physical education and sports: zb. sciences. pr. - Kharkiv: HDADM. No6. - P.74-76.

7. Laputin A. N. (1985) Athletic gymnastics / Laputin A. N. - K .: Zdorov'ya. - 112 p.

8. Matveev L. P. (2008) Teoryya y metodyka fyzycheskoy kul'turb / L. Matveev. - M. : Fyzkul'tura y sport. - $544 \mathrm{~s}$.

9. Semenovych S. (2010) Osoblyvosti vplyvu zanyat' atletychnoyu himnastykoyu na rozvytok sylovykh zdibnostey yunakiv 15-17 rokiv // Moloda sportyvna nauka Ukrayiny. - L'viv : LDIFK. - Vyp. 3. - T. 1. - S. 308-311.

10. Prykhod'ko V. V. (2008) Reformuvannya vyshchykh navchal'nykh zakladiv fizychnoyi kul'tury i sportu v Ukrayini /I Teoriya i praktyka fizychnoho vykhovannya. - №1. - S. 74-85.

11. Ogar G. O. (2011) Injection of the program of strength training with the added value of the growth of directness to the physical development and preparation of the children of 15-17 years // Theory and technique of physical education.- No.10. - P.3742.

12. Shyyan B. (2003) Teoriya i metodyka fizychnoho vykhovannya shkolyariv / B. Shyyan. - Ch. 1. - Ternopil' : Navch. kn.- Bohdan. $-272 \mathrm{~s}$. 